\title{
Tinjauan Etis atas Fenomena Relativisme Hukum dalam Kasus Pabrik Semen di Rembang
}

\begin{abstract}
Raynaldo Sembiring ${ }^{1}$
Abstrak

Kebijakan hukum yang berubah-ubah tentunya menimbulkan ketidakpastian hukum. Dalam tingkat tertentu, pertanyaan mengenai keadilan akan menjadi relevan ketika perubahan tersebut bertentangan dengan aturan yang seharusnya menjadi pedoman menjalankan pemerintahan. Apalagi jika hukum digunakan hanya untuk melegitimasi kebijakan yang dibentuk. Situasi ini disebut sebagai relativisme moral yang berimplikasi terhadap munculnya relativisme hukum. Dalam beberapa tahun terakhir, relativisme hukum dalam kebijakan perlindungan dan pengelolaan lingkungan hidup sangat sering terjadi. Salah satunya dalam kasus pembangunan pabrik Semen di Rembang. Dari kasus tersebut dapat terlihat, relativisme hukum yang menimbulkan masalah setidaknya dalam perspektif etika lingkungan dalam pelaksanaan tugas perlindungan dan pengelolaan lingkungan hidup. Oleh karena itu, artikel ini bertujuan memaparkan kondisi relativisme hukum dalam kebijakan perlindungan dan pengelolaan lingkungan hidup yang dipilih, dengan ditinjau dari pendekatan etika lingkungan.
\end{abstract}

Kata kunci: relativisme, moral, hukum, lingkungan, etika

\begin{abstract}
Fluctuating legal policies certainly cause legal uncertainty. In a certain level, questions about justice will be relevant when these changes conflict with the rules that should be a guideline for running the government. Especially if the law is used only to legitimize established policies. This situation is referred to as moral relativism which has implications for the emergence of legal relativism. Recent years, legal relativism in environmental protection and management policies are very frequent. One of them was in the case of the cement plant construction in Rembang. This case shows a legal relativism which becomes a problem at least in the perspective of environmental ethics in carrying out the task of protecting and managing the environment. Therefore, this article aims to explain how environmental ethics view the condition of legal relativism in the protection and management of the environment.
\end{abstract}

Keywords: relativism, moral, law, environmental, ethics

${ }^{1}$ Penulis adalah Deputi Direktur Indonesian Center for Environmental Law (ICEL), Pengajar Hukum Lingkungan Sekolah Tinggi Hukum Indonesia Jentera dan Dewan Daerah Walhi DKI Jakarta 2018-2022. 


\section{Pendahuluan}

Salah satu prinsip dasar dari penyelenggaraan pemerintahan yang baik adalah menjalankan pemerintahan sesuai dengan aturan yang berlaku dan menerapkan asas pemerintahan yang baik. Melanggar aturan tentunya dapat menimbulkan banyak dampak, seperti: ketidakpastian hukum, kerugian perekonomian, dan terancamnya akses keadilan masyarakat. Dalam menjalankan tugas perlindungan dan pengelolaan lingkungan hidup beberapa waktu terakhir, muncul fenomena mengenai kebijakan pemerintah yang seolah terlihat sesuai dengan hukum, tetapi secara nyata tidak mencerminkan keadilan dan masih meninggalkan permasalahan.

Fenomena seperti ini sebenarnya banyak terjadi, salah satunya adalah penerbitan izin lingkungan perubahan kepada PT Semen Indonesia (PT SI) tidak lama setelah Mahkamah Agung (MA) membatalkan izin lingkungan sebelumnya ${ }^{2}$ dan penerbitan keputusan Gubernur Jawa Tengah yang seolah-olah memenuhi putusan kasasi MA. Kasus inilah yang akan dibahas dalam tulisan, khususnya untuk menguji apakah terjadi relativisme.

Kebijakan hukum sejenis masih banyak, tetapi contoh di atas menunjukkan bagaimana kegagalan menjalankan esensi dari penyelenggaraan pemerintahan yang baik dalam kebijakan pemerintah, yang semestinya tunduk kepada aturan sebagai panduan dan batasannya. ${ }^{3} \mathrm{Ke}-$ bijakan Gubernur Jawa Tengah dalam menerbitkan izin lingkungan perubahan dan keputusan administratif selanjutnya juga menempatkan hukum sebagai "alat" legitimasi. "Alat" legitimasi yang dimaksud adalah untuk "membenarkan" kebijakan yang dibentuk. Situasi ini memantik pertanyaan sederhana mengenai apa sebenarnya phusis $^{4}$ dari hukum? Apakah hukum memang ditujukan untuk mengikuti kemauan penguasa?

Dalam perspektif hukum, secara prosedural terlihat kebijakan yang diambil tidak bermasalah. Namun rasa keadilan pasti terusik dan itu hanya dapat dipahami dan dimaknai dengan mata jiwa. ${ }^{5}$ Rasa keadilan yang dimaksud tentu saja tidak mengacu kepada persepsi subjek, melainkan kepada situasi objektif dari kesadaran moral manusia.

\footnotetext{
${ }^{2}$ Diberikan saat masih bernama PT Semen Gresik

${ }^{3}$ A. Sonny Keraf, Filsafat Lingkungan Hidup: Alam Sebagai Sebuah Sistem Kehidupan, (Yogyakarta: PT Kanisius, 2014), hlm. 220.

${ }^{4}$ Phusis dapat disebut sebagai nature atau kodrat, yang oleh Platon disebut sebagai idea. Idea adalah realitas yang bisa dipersepsi. Lihat: sebagaimana diuraikan oleh A. Setyo Wibowo, "Pengantar Sejarah Filsafat Yunani: Sofisme". (Makalah untuk Kelas Filsafat Yunani Kuno: Kaum Phusikoi di Serambi Salihara 12 Maret 2016), hlm. 20 dengan mengutip Jean-Fraçois Pradeau, Platon, l'imitation de la philosophie, Paris: Aubier, 2009, hlm. 292.

${ }^{5}$ Ibid., Bagi Platon, idea adalah tentang sesuatu yang baik. Idea tentang "keadilan" adalah tentang sesuatu yang baik yang berangkat dari pengalaman.
} 
Untuk memandunya, kita bisa mengajukan pertanyaan sederhana: apakah izin lingkungan perubahan yang diterbitkan oleh Gubernur Jawa Tengah benar-benar menjawab putusan Mahkamah Agung? Apakah ada rasa keadilan yang terusik?

Tulisan ini tidak akan membahas mengenai rasa keadilan tersebut, melainkan fokus kepada fenomena pembuatan kebijakan sesuai dengan persepsi masingmasing subjek yang lebih dari 25 abad lalu telah terjadi, yang disebut sebagai relativisme. Relativisme berkembang dalam sofisme yang fokus argumentasinya menolak kebenaran universal tertentu. ${ }^{6}$

Relativisme moral sering terjadi terutama ketika pembuat kebijakan kehilangan orientasi ${ }^{7}$ dalam menjalankan tugas dan wewenangnya. Relativisme moral berimplikasi terhadap hadirnya relativisme hukum. Penting untuk dicatat, relativisme hukum tidak sama dengan pluralisme hukum. Relativisme hukum hadir dari hilangnya orientasi moral sebagai bagian inheren dari adanya hukum. ${ }^{8}$ Sehingga tulisan ini hanya fokus dengan pertanyaan: bagaimana tinjauan etis terhadap fenomena relativisme hu- kum dalam kasus pembangunan pabrik semen di Rembang?

Pembahasan mengenai relativisme hukum dalam tulisan ini mengambil pendapat 2 tokoh Sofis, yaitu: Protagoras (490-420 SM) dan Thrasymakhos (459400 SM). Pendapat ini juga akan menjadi landasan bagi pembahasan mengenai relativisme hukum yang dalam pandangan Penulis terjadi pada kedua contoh kebijakan di atas. Selanjutnya kritik terhadap relativisme hukum ini akan didasarkan dari teori etika lingkungan. Pendapat para Sofis diambil sebagai contoh untuk menunjukkan bahwa sejak ribuan tahun lalu, hukum pun telah dipermainkan untuk kepentingan tertentu. Sedangkan etika menjadi pisau analisis untuk membedah masalah ini.

Jawaban atas masalah tersebut akan diuraikan dalam 5 bagian. Setelah bagian pendahuluan, bagian kedua akan menyampaikan sejarah relativisme moral dan hukum yang dilakukan oleh para tokoh Sofis. Bagian ketiga akan menjelaskan mengenai pembelaan terhadap relativisme dan kontra argumennya. Bagian keempat akan membahas mengenai

${ }^{6}$ Mohammad A. Shomali, Relativisme Etika: Analisis Prinsip-Prinsip Moralitas, (Jakarta: Shadra Press, 2011), hlm. 8.

7 Panduan dalam mempertanggungjawabkan setiap tindakan adalah etika. Etika merupakan sarana orientasinya. Lihat: Franz Magnis-Suseno, Etika Dasar: Masalah-Masalah Pokok Filsafat Moral, (Yogyakarta: PT Kanisius, 1987), hlm 13-14.

${ }^{8}$ Mengacu kepada mazhab hukum alam, seharusnya moral menjadi bagian tidak terpisahkan dari hukum. Disini yang dimaksud adalah hukum dalam menjalankan idea mengenai keadilan. Adanya teori separasi menjelaskan kemungkinan adanya hukum yang buruk atau tidak adil. Namun hal tersebut bukan sebagai pembenaran, karena tujuan hadirnya hukum berkaitan erat dengan idea keadilan. Penjelasan ini dikembangkan dengan menanggapi: Khudzaifah Dimiyati, et.al, Hukum dan Moral: Basis Epistemologi Paradigma Rasional H.L.A. Hart, (Yogyakarta: Genta Publishing, 2017), hlm. 34. 
etika umum dan etika lingkungan. Sedangkan, bagian kelima membahas kritik terhadap relativisme hukum dengan mendasarkan bagaimana seharusnya sikap tindak pemerintah dipandang dari konsep etika lingkungan, khususnya dalam kasus pabrik semen di Rembang. Terakhir, penulis akan memberikan simpulan dalam penutup.

Tulisan ini mengambil sudut pandang filsafat dalam membantu menjawab masalah-masalah hukum lingkungan yang diangkat. Sebagaimana disebutkan oleh Hamersma, penyelidikan filsafat dilakukan terhadap seluruh kenyataan yang lebih luas dibandingkan cabang ilmu pengetahuan. ${ }^{9}$ Filsafat digunakan karena hukum lingkungan sebagai cabang ilmu pengetahuan memiliki keterbatasan khususnya dalam menguraikan tinjauan etis dan moral dengan lebih lengkap terhadap pokok permasalahan yang diangkat.

Walaupun berangkat dari sudut pandang filsafat, tulisan ini tetap bersinggungan dengan hukum lingkungan, karena filsafat pada hakikatnya tidak bermaksud menegasikan cabang ilmu pengetahuan, bahkan memberikan ruang agar terjadi kekayaan pengetahuan. Adapun sudut pandangan etika ditarik karena melihat problematika utama tidak dapat diselesaikan hanya melalui mekanisme hukum yang berlaku, sehingga etika sebagai salah satu cabang filsafat penting untuk membongkar masalah ini. Etika bagaimana pun juga akan merefleksikan hal paling dasar dari manusia, yaitu moral.

\section{Sofisme dan Relativisme Hukum}

\section{A. Sejarah Sofisme}

Sofisme merupakan sebuah aliran yang berkembang pada masa demokrasi Yunani kuno (abad ke-5 SM). Para Sofis yang merupakan kaum pendatang di polis Athena, adalah ahli retorika yang mengisi ruang-ruang demokrasi Yunani untuk memberikan legitimasi "kebenaran" pada siapa yang membayarnya. ${ }^{10}$ Dalam memberikan "kebenaran", para Sofis menekankan argumentasi yang terlihat rasional padahal mengandung banyak sekali fallacy. ${ }^{11}$

Terlepas dari pro dan kontra mengenai baik dan buruknya sofisme, para Sofis pada dasarnya adalah pemikir cerdas dan produktif. Protagoras misalnya, ia menulis beberapa buku yang diantaranya: Wrestling, Mathematics, The State, Ambition, The Original State of Things, What is in Hades, dan Opposing Arguments

${ }^{9}$ Harry Hamersma, Pintu Masuk Ke Dunia Filsafat, (Yogyakarta: Yayasan Kanisius, 1981), hlm 10.

${ }^{10}$ Sering disebut Sofisme merupakan cikal bakal sekolah atau proses belajar berbayar yang saat ini menjadi lazim. Pada masa itu, proses belajar mengajar tidak dipungut biaya, sebagaimana yang dilakukan oleh Sokrates maupun Plato.

${ }^{11}$ A. Setyo Wibowo, op.cit., hlm. 1. 
(yang juga dikenal sebagai “Truth"). ${ }^{12}$

Contoh tersebut di atas menunjukan bahwa para Sofis memiliki kemampuan intelektual yang mumpuni ${ }^{13}$ dan tidak hanya "menjual" retorika "kosong" saja. Juga perlu ditegaskan sisi positif dari Sofisme adalah membawa manusia meninggalkan kepercayaan terhadap mitologi dewa-dewi Yunani kuno. Selain para kaum Phusikoi, para Sofis juga yang mulai mengajar penggunaan akal budi dalam menyelidiki fenomena-fenomena. Di kemudian hari perkembangan ini dikenal sebagai "subjektivitas" yang berkembang pesat di era pencerahan.

Demokrasi di Athena memberikan tempat pada kebebasan berpendapat. Pertarungan ide dan gagasan menjadi kesempatan bagi para kaum Sofis untuk menawarkan jasa dalam memberikan legitimasi "kebenaran". Akibatnya kebenaran dan keadilan bagi kaum Sofis adalah sekadar konvensi belaka yang bersifat relatif. Ia dapat berubah sesuai dengan kesepakatan pembuatnya. ${ }^{14} \mathrm{Ke}$ sepakatan ini perlu dipahami tidak lahir dari moral otonom, melainkan dari penilaian yang menempatkan manusia dan keinginannya sebagai alat ukurnya. Bisa dibayangkan bagaimana keguncangan yang dirasakan oleh penduduk Athena karena nilai keadilan yang mereka pahami dari mitologi dewa-dewi seakan runtuh karena argumentasi para Sofis yang menempatkannya seolah-olah adalah "semu".

Dalam sofisme, ide mengenai keadilan bukan bersifat universal. Sementara itu, ketika keadilan bukanlah sesuatu yang universal, maka akan timbul "tegangan" mengenai rasa keadilan seseorang dengan orang lain atau suatu kelompok dengan kelompok lainnya. Keadilan, walaupun sulit untuk didefinisikan dapat dipahami setiap orang dengan menggunakan moral sebagai panduannya. Hal ini yang tidak terjadi kepada para Sofis, karena moral diabaikan demi tujuan tertentu.

Ada beberapa tokoh sofisme yang dikenal. Namun, yang akan disampaikan di sini adalah pemikiran dari Protagoras dan Thrasymakhos, terutama mengenai konsepsi moral dan hukum. Pemikiran Protagoras dan Thrasymakhos sesuai dengan bahasan tulisan ini sehingga akan memudahkan untuk memahami apa itu relativisme hukum. Secara khusus, Protagoras merupakan tokoh kunci dari pemikiran relativisme yang berkembang

${ }^{12}$ David Wolfsdorf, "Sophistic and Method Practice" dalam W. Martin Bloomer (ed), A Companion to Ancient Education: Blackwell companions to the ancient world, (John Wiley \& Sons, 2015), hlm. 70.

${ }^{13}$ Walaupun bagi Platon para Sofis tidak memiliki kompetensi karena umumnya tidak dapat membuktikan apa yang mereka dalilkan. Platon menyebut mereka sebagai pseudo-practitioners of Sophia. Ibid., hlm. 63.

${ }^{14}$ A. Setyo Wibowo, op.cit., hlm. 1. 
sampai saat ini. Sedangkan, Thrasymakhos dirujuk karena pendapatnya dapat melengkapi pendapat Protagoras.

Penulis menyadari bahwa memilih Protagoras dan Thrasymakhos pada tulisan ini artinya jauh kembali ke masa lalu yang konteksnya tentu berbeda dengan masa kini. Beberapa pemikir masa kini pun sudah banyak yang membahas mengenai relativisme seperti: Nelson Goodman, Richard Rortry, dan Mohammad A. Shomali. Namun, Protagoras dan Thrasymakhos adalah cikal bakal dari hadirnya relativisme dalam kehidupan berdemokrasi, dengan sistem hukum yang tertata dan yang paling penting mereka bukan hanya pemikir, tetapi juga "praktisi" relavitisme moral dan hukum.

\section{B. Relativisme Moral dan Hukum: Protagoras dan Thrasymakhos}

Relativisme moral lahir dari tindakan para Sofis yang menyingkirkan penilaian moral dalam membangun argumentasinya. Bagaimana pun, moral adalah panduan yang berada dalam kondisi objektif. Artinya, setiap manusia dapat memahami ada perbuatan yang baik dan buruk dengan mengacu kepada moralitas. Untuk memahami bagaimana relativisme moral, dapat mengacu kepada pendapat Protagoras, yang menyebutkan: man is the measure of all things. ${ }^{15}$
Menempatkan manusia sebagai ukuran, maka jelas bagi Protagoras tidak ada nilai atau hal lain yang patut dipertimbangkan dalam membuat sebuah hukum. Jika hukum ditujukan untuk mendapat keadilan, maka bagi Protagoras adalah keadilan sesuai apa yang diinginkan manusia tersebut. ${ }^{16}$ Bahkan, jika pandangan manusia berbeda-beda mengenai keadilan itu, maka keadilan juga harus dipahami sesuai dengan kepentingan masing-masing kelompok. Artinya keadilan tidak mungkin akan mempersatukan karena ia ada sesuai dengan kepentingan setiap kelompok bahkan sampai kepada individu.

Gambaran mengenai pemikiran Protagoras terlihat dari pendapatnya mengenai persepsi atas suhu. Ini terlihat pada komentar Platon dalam Theaetetus $152 a$ mengenai suhu yang dirasakan berbeda oleh dua orang. Penulis mencoba memberikan contoh dari komentar Platon tersebut. Lebih kurang seperti ini: jika ada dua orang ( $X$ dan $Y$ ) dalam satu ruangan di Jakarta yang memiliki Air Conditioner (AC) dengan temperatur $16^{\circ} \mathrm{C}$, bagi $X$ suhu ruangan adalah dingin, tetapi bagi $Y$ suhu ruangan adalah panas. Terhadap dua persepsi atas suhu yang berbeda ini, Protagoras berpendapat bahwa suhu di ruangan tersebut tidak dingin ataupun panas, melainkan

\footnotetext{
${ }^{15}$ Plato, Theaetetus, terjemahan oleh John McDowell, (Oxford: Clarendon Press, 1973). Theaetetus 152 ${ }^{16}$ Ibid.
} 
dingin dan panas. ${ }^{17}$ Jadi dingin dan panasnya suhu tersebut tergantung kepada persepsi yang merasakannya. Jika $X$ merasakan dingin, maka itu adalah kebenaran baginya dan jika Y merasakan panas, maka itu juga kebenaran baginya.

Berdasarkan contoh di atas, maka kebenaran didasarkan pada persepsi setiap orang. Hal ini wajar, karena Protagoras menempatkan manusia sebagai ukuran. Menempatkan manusia sebagai ukuran (persepsi manusia), maka menghadirkan apa yang disebut sebagai relativisme. Kembali kepada contoh di atas, maka fungsi dari AC yang seharusnya dapat menjadi pengukur dingin, tidak dingin atau panasnya suhu ruangan menjadi tidak penting. $16^{\circ} \mathrm{C}$ dalam ruangan di Jakarta dapat secara umum dikatakan dingin. Namun, data ini menjadi tidak penting, jika persepsi $Y$ menyatakan bahwa ruangan tersebut adalah panas. Intinya, kembali ke persepsi masing-masing orang dan itulah kebenaran.

Relativisme yang disampaikan oleh Protagoras dapat dikatakan sebagai yang tertua jika batasannya adalah relativisme yang memiliki basis argumentasi. Pandangan utuh relativisme sebenarnya disampaikan pada tulisannya yang berjudul Truth. Namun, tulisan ini sudah hilang sehingga pemikiran Protagoras hanya dapat dipelajari melalui tulisan Platon. ${ }^{18}$

Terhadap pemikiran Protagoras, dengan mengembangkan pendapat Brandt, Shomali menjelaskan bahwa Protagoras sejatinya ingin menjelaskan: (i) pandangan moral tidak dapat dibuktikan benar pada setiap orang; dan (ii) orang harus mengikuti kesepakatan tidak tertulis kelompoknya sendiri. ${ }^{19}$ Bagi Shomali, pendapat pertama menjadi dasar bagi pendapat kedua. Sehingga sebaik apapun pembelaan terhadap Protagoras, sulit untuk menolak bahwa moral dan juga hukum dapat diletakkan di mana saja sesuai dengan persepsi.

Tokoh Sofis lainnya adalah Thrasymakhos yang menyebutkan bahwa hukum adalah hasil produksi dari kesepakatan para penguasa. Thrasymakhos, sebagaimana dikutip oleh Platon dalam The Republic 338c menyatakan: I affirm that the just (to dikaion) is nothing else than the advantage of the stronger. ${ }^{20}$ Intinya Thrasymakhos menekankan bahwa apa yang adil adalah menurut hukum yang dibuat oleh penguasa, sebagai keuntungan bagi orang "kuat". ${ }^{21}$ Bagi Th-

\footnotetext{
${ }^{17}$ John Gibert, "The Sophists" dalam Christopher Shields (ed), The Blackwell Guide to Ancient Philosophy, (Blackwell Publishing Ltd, 2003), hlm. 41.

${ }^{18}$ Khususnya dalam dialog antara Sokrates dengan Theaetetus yang terangkum dalam Theaetetus 152a-179b dan 170e-171c. Plato, op.cit., Theaetetus 152a-179b dan 170e-171c.

${ }^{19}$ Mohammad A. Shomali, Relativisme Etika: Analisis Prinsip-Prinsip Moralitas..., hlm. 24.

${ }^{20}$ A. Setyo Wibowo, Paideia: Filsafat Pendidikan-Politik Platon, (Yogyakarta: Penerbit Kanisius, 2017), hlm. 203.

${ }^{21}$ A. Setyo Wibowo, “Pengantar Sejarah Filsafat Yunani: Sofisme, hlm. 3.
} 
rasymakhos hukum yang dibuat oleh penguasa yang disebut keadilan itu bisa jadi baik bagi sebagian orang dan buruk bagi yang lainnya. Adapun ketidakadilan adalah kebalikannya, sehingga orang yang bersikap adil selalu memiliki kekurangan dari yang tidak adil..$^{22}$

Argumentasi Thrasymakhos dibangun dari pandangan pseudo-naturalisme (karena para Sofis sebenarnya tidak setuju dengan hukum alam, tetapi tidak menjadi penting karena mereka juga merelatifkan semua hal) bahwa alam telah menempatkan yang kuat sebagai penguasa (seperti hukum rimba). Karena yang kuat dapat mengatasi yang lemah, maka yang kuat berhak menjadi pemimpin/ penguasa dan hukum yang dibuat berasal dari padanya. Thrasymakhos menegaskan kembali pandangannya bahwa hukum itu adalah kebutuhan yang kuat. Penguasa membutuhkan hukum untuk melindungi apa yang menjadi kepentingannya. Sedangkan yang lemah tidak membutuhkan hukum karena sedari awal sudah kalah dan berada dalam "kepasrahan" mengikuti yang kuat.

Dalam dialog di The Republic 340c-341a, Sokrates mempertanyakan bilamana ternyata hukum itu dibuat oleh pemimpin atau penguasa yang jahat, apakah hukum itu juga dapat dikatakan adil? Thrasymakhos menjawab bahwa pemimpin/penguasa tidak mungkin orang yang buruk atau jahat. Mereka adalah infallible (tidak bisa salah) sehingga apa yang dilakukannya dapat dikatakan "sempurna". ${ }^{23}$

Pendapat Protagoras mengenai relativisme dan Thrasymakhos mengenai hukum dan keadilan, menjadi landasan penting bagi praktik Sofisme di Polis Athena. Kombinasi dari kedua pendapat ini menghasilkan beberapa hal penting yang coba disederhanakan Penulis sebagai bahasan dalam tulisan ini, sebagai berikut:

1. Relativisme pada satu tahap akan mengenyampingkan data Data hanya akan relevan selama sesuai dengan persepsi manusia. Data yang dimaksud di sini berasal dari sebuah proses metodologi ilmu pengetahuan yang sahih. Adapun hukum, dapat dibuat tanpa data dan cukup hanya dengan persepsi. Dalam hal adanya perubahan persepsi, maka di saat itu juga hukum dapat berubah mengikuti persepsi. Di sini jelas terlihat bahwa relativisme yang dimaksud berbeda dengan pluralisme hukum yang mengakui keragaman pada masing-masing kelompok masyarakat. Relativisme yang diusung oleh Protagoras hadir tidak dengan orisinalme, melainkan dengan intensi

\footnotetext{
${ }^{22}$ John Gibert, “The Sophists” dalam Christopher Shields (ed), The Blackwell Guide to Ancient Philosophy,....., hlm. 39 .

${ }^{23}$ A. Setyo Wibowo, Paideia: Filsafat Pendidikan-Politik Platon, hlm. 205.
} 
dan kepentingan tertentu yang jauh dari orientasi moral.

2. Persepsi dibangun berdasarkan kepentingan

Jika data diabaikan dan hanya mengandalkan persepsi, berarti mengandaikan adanya kepentingan mempengaruhi persepsi itu. Manusia sebagai pengada hidup adalah penentu finalitas yang dilakukan dengan kegiatan transitif. ${ }^{24}$ Sehingga keinginannya akan mempengaruhi persepsinya terhadap banyak hal, termasuk yang menyangkut urusan publik (hukum dan keadilan). Penegasannya, dengan perkembangan zaman dan kehidupan di masyarakat, tidaklah mungkin persepsi dapat berdiri kokoh tanpa terpengaruh faktor eksternal. Sejatinya, persepsi adalah bentuk dari kehadiran dan kepentingan subjek.

3. Hukum akan menjadi "alat" legitimasi dari persepsi penguasa

Ketika keadilan menjadi keuntungan bagi yang kuat, maka hukum harus dibuat sesuai dengan apa yang dianggap adil. Dalam hal rasa keadilan dipertanyakan oleh masyarakat, itu tidak akan menjadi penting karena keadilan telah dibungkus oleh hukum sebagai legitimasi atas apa yang ditentukan adil. Terlepas dari pro kontra bahwa hukum dapat digunakan sebagai alat. Penulis menekankan kepada aspek moralitas yang tidak dapat dipisahkan dari hukum.

4. Adanya negasi terhadap peran insitusi-institusi penegakan hukum

Relativisme hukum mengandaikan nihilnya universalitas keadilan. Apa yang adil, tidak dapat ditentukan oleh pengadilan atau institusi penegakan hukum. Adil adalah apa yang sesuai dengan hukum yang dibentuk dari persepsi penguasa. Di sini penekanannya pada perspesi yang membentuk hukum. Sehingga jika itu dianggap adil, maka makna mengenai keadilan akan menjadi sangat sempit.

5. Terciptanya relativisme hukum Relativisme awalnya bersinggungan erat dengan moral, tetapi dalam hal argumentasi relatif tersebut menjadi sebuah hukum, maka di saat itu juga terjadi relativisme hukum. Hukum tidak mungkin dijalankan tanpa adanya moralitas dan ketika moralitas runtuh, maka hukum pun akan terdampak. Relativisme hukum bukanlah pluralisme hukum, karena yang dikritik bukan dari keragamanannya, melainkan tujuan dan proses pembentukannya yang dominan pada persepsi subjek.

${ }^{24}$ Louis Leahy, "Siapakah Manusia? Sintesis Filosofis tentang Manusia”, (Yogyakarta: Penerbit Kanisius, 2001), hlm. 67. 


\section{Pembelaan terhadap Relativisme dan Kontra Argumennya}

Sebelum sampai kepada pembahasan mengenai tinjauan etis terhadap problematika yang diangkat, penting membahas bagaimana pembelaan terhadap relativisme Protagoras yang disampaikan oleh pemikir masa kini. Pembelaan terhadap relativisme umumnya didasarkan pada hukum kebiasaan atau adat istiadat yang berbeda-beda.

William Graham Sumner dan Edward Westermarck termasuk tokoh yang memberikan pembelaan terhadap relativisme moral. Sumner yang seorang antropolog menyatakan bahwa moralitas seharusnya dapat dibagi 2, yaitu moralitas aktual dan moralitas ideal. ${ }^{25}$ Bagi Sumner moralitas yang hidup dalam tradisi rakyat adalah moralitas aktual. Karena tradisi akan berbeda-beda, maka moralitas aktual merupakan pembenaran bagi adanya relativisme moral. ${ }^{26}$

Berbeda dengan Sumner yang masih mencari "jalan tengah" terhadap relativisme moral, Westermarck dengan tegas membela keyakinannya akan kebenaran relativisme moral. Dalam pengantar di bukunya Ethical Relativity, Westermarck menjelaskan bahwa moral tidak pernah berada pada kondisi objektif. Artinya tidak ada universalitas mengenai moral. Bagi Westermarck putusan-putusan moral hanya didasarkan dari kecenderungan emosional. ${ }^{27}$

Kecenderungan emosional bagi Westermarck tidak serta merta menghilangkan ruang bagi rasio. Namun, "emosi" menjadi dominan bagi pengambilan keputusan moral, dan emosi akan bersinggungan dengan subjektivitas. ${ }^{28}$ Artinya Westermarck setuju dengan relativisme Protagoras yang menekankan kepada aspek persepsi subjek.

Terhadap pembelaan yang diajukan Sumner dan Westermarck, Penulis mencoba memberikan kontra argumen. Pendapat Sumner memang benar, tetapi harus dilihat bahwa nilai yang hidup dalam tradisi masyarakat tidak serta merta menunjukkan adanya relativisme. Karena pada esensinya nilai mengenai apa yang baik, akan selalu sama pada seluruh manusia berakal budi. Mengutip Shomali, apa yang disampaikan Sumner lebih tepat disebut sebagai "keragaman moral" ${ }^{29}$

Adapun terhadap Westermarck, emosi subjek dalam pengambilan putusan moral memang ada, tetapi tidak serta

${ }^{25}$ William Graham Sumner dalam Folkways, sebagaimana dikutip oleh Mohammad A. Shomali, Relativisme Etika: Analisis Prinsip-Prinsip Moralitas..., hlm. 34.

${ }^{26}$ Ibid.

${ }^{27}$ Edward Westermarck, Ethical Relativity, (London: Kegan Paul, Trench, Trubner \& Co Ltd, 1932), hlm. xvii.

${ }^{28}$ Mohammad A. Shomali, Relativisme Etika: Analisis Prinsip-Prinsip Moralitas..., hlm. 39.

${ }^{29}$ Ibid., hlm. 53. 
merta juga dapat digeneralisasi bahwa proporsinya sangat besar sampai mendominasi rasio. Unsur emosi tidak akan pernah hilang dari subjek baik dalam mengambil putusan moral ataupun hal lain di kehidupannya. Jika adanya emosi menjadi pembenaran bagi relativisme, maka pendapat yang disampaikan oleh Protagoras, Thrasymakhos, Sumner, Westermarck dan para relativis lainnya juga dapat disebut sebagai relatif. Artinya, tidak perlu kita memahami pendapat mereka, karena tidak akan dapat digunakan dalam kehidupan sosial.

\section{Etika Umum dan Etika Lingkungan}

\section{A. Etika Umum}

Etika merupakan cabang filsafat dan studi interdisipliner. Pada mulanya, fokus etika diarahkan kepada manusia. Diskusi mengenai etika akan menyangkut mengenai baik dan buruk suatu perbuatan manusia. Sehingga di sini ada kaitan erat antara etika dengan moral. ${ }^{30}$ Moralitas sendiri merupakan ciri khas manusia yang terbentuk dari hubungan antara manusia dalam menjalankan kebebasan sosialnya. ${ }^{31}$ Secara individu, manusia juga memiliki kebebasan eksisten- sial, di mana kebebasan ini merupakan hak dasar dari manusia. Dengan kata lain, dalam menjalankan eksistensinya (kebebasan eksistensial) sebagai manusia dalam pergaulan sosial (kebebasan sosial), penting membicarakan moral.

Diskursus mengenai kebebasan manusia yang sampai sekarang masih terjadi umumnya dilandaskan pada pemahaman bahwa manusia adalah makhluk berakal budi yang memiliki kesadaran dan pengertian. Lahirnya kebebasan adalah transformasi dari sadarnya manusia akan eksistensi dirinya melalui kesadaran dan pengertian. ${ }^{32}$ Kesadaran, pengertian dan kebebasan merupakan kata-kata kunci yang menjadi pangkal pelaksanaan perbuatan manusia. Bagaimana dengan makhluk hidup lainnya? Apakah hewan dan tumbuhan memiliki kesadaran? Secara filosofis, jawabannya adalah ya, walaupun dalam ukuran yang sangat rendah jika dibandingkan dengan manusia. Namun tidak serta merta kesadaran yang dimilikinya menjelaskan bahwa mereka juga memiliki pengertian dan kebebasan.

Kembali kepada etika, seperti telah disinggung sebelumnya, etika secara eti-

${ }^{30}$ Etika berasal dari kata Yunani yaitu ethos yang berarti adat istiadat atau kebiasaan. Pengertian ini sama dengan moral yang berasal dari kata latin mos yang berarti juga adat istiadat atau kebiasaan. Ethos dan mos digunakan untuk sesuatu yang baik. Namun pemaknaan antara etika dan moral dapat dilihat dari berbagai sudut pandang, Lihat: A. Sonny Keraf, Etika Lingkungan, (Jakarta: Kompas, 2010), hlm. 14-15.

${ }^{31}$ K. Bertens, Etika, (Jakarta: Gramedia Pustaka Utama, 2011), hlm. 11.

${ }^{32}$ Louis Leahy, op.cit., hlm. 158-161. 
mologis adalah kebiasaan, watak atau kelakuan manusia. ${ }^{33}$ Pengertian etika setidaknya dapat dibagi menjadi 3, yaitu: (i) sebagai sistem nilai, di mana nilai-nilai dan norma-norma dijadikan pegangan hidup untuk menilai yang baik dan buruk; (ii) kode etik ${ }^{34}$; dan (iii) sebagai refleksi kritis dan sistematis atas moralitas. ${ }^{35}$ Ada 3 teori etika normatif yang umumnya dikenal:

1. Etika teleologis/konsekuensialis Etika yang memberikan jawaban bagaimana bertindak dalam situasi konkret tertentu dengan melihat tujuan atau akibat dari suatu tindakan. Intinya, dalam bertindak terhadap situasi konkret tertentu maka harus memilih tindakan yang membawa akibat baik. ${ }^{36}$ Persoalan yang muncul dalam etika adalah penentuan "tujuan baik." Terdapat beberapa teori dalam etika teleologis, yaitu: keuntungan pribadi (egoism), kebahagian (eudaimonism), kenikmatan (hedonism) dan manfaat (utilitarianism). Dari keempatnya, yang sering digunakan dalam pengambilan keputusan untuk kebijakan adalah utilitarianisme.
Teori utilitarianisme menyatakan bahwa yang baik adalah sejauh memajukan kebahagian dan yang buruk adalah kebalikan dari kebahagiannya tersebut. ${ }^{37}$ Kebahagian yang dimaksud adalah kebahagian umum, sehingga penganut utilitarian akan berpedoman kepada the greatest happiness of the greatest number.

2. Etika deontologis/non-onsekuensialis

Etika deontologis diperkenalkan oleh filsuf besar, Immanuel Kant (1724-1804). Etika deontologis memberikan kritik keras terhadap etika teleologis, karena akibat dari baik dan buruk itu pada dasarnya bertujuan untuk menguntungkan pelakunya. ${ }^{38}$ Menurut Kant, manusia baru bersikap moral sungguh-sungguh karena mematuhi kewajiban moralnya berdasarkan sikap hormat terhadap hukum moral. ${ }^{39}$ Artinya, motif dari suatu tindakan itu bukanlah karena ingin mendapatkan keuntungan, ingin dipuji, dan ingin dikenal. ${ }^{40}$ Motifnya harus sikap tindak murni dan sungguh-

${ }^{33}$ J. Sudarminta, Etika Umum: Kajian tentang Beberapa Masalah Pokok dan Teori Etika Normatif, (Yogyakarta: PT Kanisius, 2013) hlm. 1.

${ }^{34}$ sebagai kumpulan nilai dan norma yang wajib dijunjung dalam menjalankan profesi tertentu

${ }^{35} \mathrm{Ibid}$.

${ }^{36}$ A. Sonny Keraf, Etika Lingkungan, (Jakarta: PT Kompas Media Nusantara, 2010), hlm. 29.

${ }^{37}$ Pendapat ini disampaikan oleh John Stuart Mill. Lihat: Alex Lanur "Pengantar Edisi Indonesia" dalam John Stuart Mill, On Liberty, (Jakarta: Yayasan Obor Indonesia, 2005).

${ }^{38}$ J. Sudarminta, op.cit., hlm. 136.

${ }^{39}$ Ibid.

${ }^{40}$ Dalam pandangan Penulis, perlu dijelaskan bahwa sikap seperti ini bukanlah tidak bermoral. Namun moralnya adalah netral. 
sungguh hormat terhadap hukum moral.

3. Etika keutamaan

Etika keutamaan menjawab pertanyaan mengenai mau menjadi manusia seperti apa aku ini? Apa saja keutamaan-keutamaan yang perlu kukejar? Berbeda dengan dua teori etika sebelumnya fokus pada ethics of doing, etika keutamaan fokus pada ethics of being. ${ }^{41}$ Beberapa tokoh etika keutamaan adalah Aristoteles dan Thomas Aquinas.

Dari ketiga teori etika normatif ini, Penulis memilih menggunakan etika deontologis Kant dalam pembahasan dengan teori etika lingkungan pada bagian selanjutnya. Hal ini karena etika keutamaan terlalu menekankan kepada pembentukan watak atau karakter sedangkan etika teleologis merupakan antithesis dari etika deontologis dan justru akan bertentangan dengan etika lingkungan yang mendorong adanya harmonisasi di antara makhluk hidup.

Adapun etika deontologis Kant menekankan pada akal budi murni dan bukan pada kegunaan atau nilai lainnya. Bagi Kant, sikap tindak manusia itu bukan hanya berdasarkan kewajiban, melainkan juga demi kewajiban. ${ }^{42}$ Hal ini seusai dengan idea dari etika lingkungan yang menekankan pada sikap hormat kepada alam, bukan karena misalnya kita butuh oksigen maka kita tidak merusak hutan, melainkan karena merupakan bagian dari kehidupan yang sama dengan kita.

Dalam menjalankan etika deontologis, Kant memberikan 2 rumusan pokok. Pertama, manusia harus bertindak sedemikian rupa agar prinsip atau kaidah tindakan tersebut bisa sekaligus kita kehendaki sebagai prinsip atau kaidah tindakan yang berlaku umum. Rumusan pertama ini dikenal sebagai imperatif kategoris. Kedua, manusia harus bertindak memperlakukan kemanusiaan baik pada diri sendiri maupun orang lain sebagai tujuan dalam dirinya sendiri, bukan hanya sebagai sarana. ${ }^{43}$ Sederhananya, aplikasi etika deontologis dalam problematika lingkungan terlihat dari penolakan terhadap superioritas manusia atas makhluk hidup lainnya. Kedua rumusan pokok tersebut pada dasarnya selaras dengan apa yang akan dibahas pada bagian berikut.

\section{B. Etika Lingkungan dan Relativisme}

Perkembangan etika lingkungan sebagai salah satu cabang keilmuan dalam filsafat bersumber dari perkembangan ilmu pengetahuan dan teknologi sejak era modern. Era di mana subjektivitas

\footnotetext{
${ }^{41}$ J. Sudarminta, op. cit., hlm. 156.

${ }^{42}$ Ibid., hlm. 137.

${ }^{43}$ Ibid., hlm. 138.
} 
berkembang, manusia semakin otonom dan menyingkirkan berbagai faktor determinan yang dahulu terlihat absolut.

Pengaruh Descartes yang rasionalis ${ }^{44}$ dan Newton ${ }^{45}$ sebagai penemu hukum gravitasi membawa manusia kepada konsepsi universalitas. Konsepsi universalitas ditunjukkan dengan bagaimana kebenaran yang didapat melalui metodologi sains dan teknologi cenderung dipaksakan sebagai kebenaran umum. Era modern disebut menganut paradigma mekanistis terhadap alam. Paradigma mekanistis menempatkan alam seperti sebuah "mesin" yang hanya dapat dijalankan dengan memahami bagian-bagiannya secara terpisah. ${ }^{46}$

Relativisme dengan etika lingkungan dihubungkan oleh subjektivitas. Subjektivitas hadir dengan mengagungkan kemampuan rasio yang dalam konteks etika lingkungan akan memandang alam sebagai "mesin". Adapun relativisme jelas-jelas mengedepankan persepsi yang asal muasalnya dari rasio. Sehingga rasio akan mencari pembenaran bagi tindakannya, yang kemudian melahirkan relativisme.

Perkembangan etika lingkungan tidak dapat dipisahkan dari perkembangan gerakan lingkungan hidup global. Eskalasi gerakan lingkungan mendapat momentumnya melalui terbitnya Silent Spring yang kemudian diikuti oleh gerakan lanjutan seperti gerakan untuk hari bumi dan pemikiran-pemikiran etika lingkungan. Rachel Carson melalui Silent Spring harus diakui sebagai penggerak perubahan cara pandang manusia terhadap alam. Sebagai seorang bilogist, Carson menunjukkan bagaimana tindakan penghancuran lingkungan yang dilakukan tersebut mengakibatkan perubahan pada alam. Salah satunya adalah hilangnya suara hewan tertentu yang biasanya ditemui pada musim semi. ${ }^{47}$

Setelah Carson gerakan lingkungan yang kemudian melahirkan etika ling-

${ }^{44}$ Rasionalisme Descartes terlihat dari argumentasinya mengenai pikiran manusia, terutama dalam meditasi pertama dan kedua. Lihat: René Descartes, Meditation on First Philosophy, (New York: Oxford University Press Inc, 2008), hlm. 13-24.

${ }^{45}$ Pentingnya Newton dalam perkembangan ilmu pengetahuan membuat Alexander Pope memperkenalkan sebuah kutipan "Nature and Nature's laws lay hid in night: God said, Let Newton be! and all was light."

${ }^{46}$ A. Sonny Keraf, Filsafat Lingkungan Hidup: Alam Sebagai Sebuah Sistem Kehidupan, hlm. 13.

${ }^{47}$ Rachel Carson, Silent Spring, (New York: Fortieth Anniversary Edition, A Mariner Book, Houghton Mifflin Company, 2002), hlm. 2 
kungan banyak dipengaruhi oleh pemikir-pemikir yang beberapa di antaranya tertulis di bawah ini.

\begin{tabular}{|c|c|l|}
\hline Waktu & Penggerak & \multicolumn{1}{|c|}{ Pokok Pikiran } \\
\hline 1949 & Aldo Leopold & $\begin{array}{l}\text { Menerbitkan Land Ethic yang menolak } \\
\text { paradigma mekanistis para pemikir sejak era } \\
\text { modern yang menganggap bumi sebagai } \\
\text { media yang siap untuk dieksploitasi kapan } \\
\text { saja. }\end{array}$ \\
\hline 1960-an (awal) & $\begin{array}{l}\text { Rachel Louise } \\
\text { Carson }\end{array}$ & $\begin{array}{l}\text { Menentang penggunaan pestisida yang } \\
\text { berbahaya bagi kesehatan manusia dan } \\
\text { lingkungan. }\end{array}$ \\
\hline
\end{tabular}

\begin{tabular}{|c|c|c|}
\hline 1968 & Paul Ralph Ehrlich & $\begin{array}{l}\text { Menerbitkan Population Bomb yang } \\
\text { memberikan peringatan akan prediksi } \\
\text { pertumbuhan umat manusia yang akan } \\
\text { mengancam sistem penunjang kehidupan. }\end{array}$ \\
\hline 1972 & $\begin{array}{c}\text { Kelompok Roma } \\
\text { (Dennis Meadows, } \\
\text { Donella Meadows, } \\
\text { Jørgen Randers, } \\
\text { William W. Behrens } \\
\text { III, dkk) }\end{array}$ & $\begin{array}{l}\text { Menerbitkan Limits to Growth sebuah } \\
\text { laporan hasil simulasi komputer mengenai } \\
\text { pertumbuhan ekonomi eksponensial, } \\
\text { pertumbuhan penduduk dan keterbatasan } \\
\text { sumber daya alam. Disini telah ada } \\
\text { pengembangan etika lingkungan hidup } \\
\text { sebagai bagian dari filsafat moral terapan. }\end{array}$ \\
\hline $1972-1973$ & $\begin{array}{l}\text { Arne Dekke } \\
\text { Eide Næss }\end{array}$ & $\begin{array}{l}\text { Menerbitkan The Shallow and the Deep, } \\
\text { Long-range Ecological Movement: A Summary } \\
\text { yang memperkenalkan deep ecology sebagai } \\
\text { kritik atas shallow ecological movement yang } \\
\text { berpandangan menyelesaikan masalah } \\
\text { lingkungan dengan pendekatan teknis tanpa } \\
\text { perubahan perilaku dan kesadaran. }\end{array}$ \\
\hline 1975 & $\begin{array}{c}\text { Peter Albert David } \\
\text { Singer }\end{array}$ & $\begin{array}{l}\text { Menerbitkan Animal Liberation: A New } \\
\text { Ethics for our Treatment of Animals yang } \\
\text { memperkenalkan prinsip moral yang sama } \\
\text { diantara semua spesies (penekanan pada } \\
\text { hak satwa). }\end{array}$ \\
\hline
\end{tabular}




\begin{tabular}{|l|l|l|}
\hline 1986 & Paul W. Taylor & Menerbitkan Respect for Nature: A Theory \\
& of Environmental Ethics, memperkenalkan \\
& biosentrisme yang menekankan kepada \\
& kewajiban moral terhadap alam yang \\
& bersumber dan berdasarkan pada \\
& perimbangan nilai kehidupan manusia dan \\
& spesies lainnya. Teori ini berpusat pada \\
& kehidupan.
\end{tabular}

\section{Tabel 2. Perkembangan Gerakan Lingkungan dan Etika Lingkungan}

Perkembangan pemikiran etika lingkungan dalam tabel di atas, didasarkan dari refleksi atas sikap tindak manusia terhadap alam. Berbeda dengan etika umum yang fokus kepada sikap tindak manusia sebagai pelaku moral, maka etika lingkungan berupaya memasukkan lingkungan hidup atau alam semesta sebagai bagian dari komunitas moral. ${ }^{48}$ Di sini yang dituntut tidak hanya sikap tindak manusia yang baik untuk alam, melainkan bagaimana relasi di antara semua kehidupan alam semesta, baik antara manusia dengan manusia yang memiliki dampak ke alam, maupun antara manusia dengan alam itu sendiri. ${ }^{49}$

Mengacu kepada Keraf, setidaknya ada 5 teori etika lingkungan yang dikenal, di antaranya adalah: antroposentrisme, biosentrisme, ekosentrisme, hak asasi alam dan ekofeminisme. ${ }^{50}$ Pembahasan ini menekankan pada pendekatan antroposentrisme dan biosentrisme, yang sesuai dengan jangkauan konstitusi dan regulasi yang berkembang di Indonesia.

\section{Antroposentrisme}

Pembahasan antroposentrisme dalam etika lingkungan sedikit banyak sama dengan pembahasan etika normatif. Hal ini wajar karena pendekatan antroposentrisme menekankan manusia sebagai pusat dari alam semesta. Tidak ada yang salah dengan konsep ini sampai dengan pemikiran berkembang kepada manusia dan kepentingannya dianggap yang paling menentukan dalam tatanan ekosistem serta kebijakan yang diambil terkait dengan alam. ${ }^{51}$ Pemikiran ini sesuai dengan apa yang terjadi pada era modern, di mana rasio sangat diunggulkan sehingga melahirkan subjektivitas. Jika sikap dan tindak manusia hanya diukur dari tujuan atau akibatnya, maka perlindungan terha-

\footnotetext{
${ }^{48}$ A. Sonny Keraf, Etika Lingkungan, op.cit., hlm. 40.

${ }^{49}$ Ibid., hlm. 41-42.

${ }^{50}$ Ibid.

${ }^{51}$ A. Sonny Keraf, Etika Lingkungan, op.cit., hlm. 47.
} 
dap kepentingan alam tidak mendapat tempat. Apalagi jika kebahagian umum diukur berdasarkan angka terbesar, maka akan sulit mengukur perbandingan antara kepentingan "manusia vs alam". Karenanya, pendekatan seperti utilitarian dalam etika teleologis tidak akan sesuai dengan apa yang dimaksud etika lingkungan.

Etika deontologis Kant memiliki relevansi erat dalam menempatkan pendekatan antroposentrisme yang bijak terhadap alam. Mengacu kepada etika deontologis Kant, maka pendekatan antroposentrisme juga seharusnya dapat menggunakan dua rumusan pokok tersebut. Pertama, secara imperatif kategoris sikap tindak manusia terhadap alam harus mencerminkan hormat kepada alam. Hormat terhadap alam adalah menghilangkan superioritas dalam interaksi dengan alam. Hal ini perlu dilakukan agar manusia lain juga melakukan hal yang sama. Sebagai contoh, manusia paham bahwa ada kewajibannya terhadap alam untuk menjaga kualitas air sungai tetap baik, maka kita tidak membuang sampah ke sungai dan sikap tindak ini dapat diberlakukan secara umum. Ke- dua, sikap tindak hormat kepada alam merupakan bagian integral dari perilaku sehari-hari. Sehingga penggunaan akal budi dan motif kita adalah murni karena kewajiban kita menjaga alam. Penting untuk dipahami bahwa etika deontologis Kant menghasilkan objektivitas kesadaran moral, yang melawan subjektivitas dan relativisme..$^{52}$ Walaupun Hegel memberikan kritik bahwa etika deontologis Kant dapat mengarah kepada individualisme subjektif, ${ }^{53}$ itu hanya terjadi pada penyalahgunaan akal budi. Pendapat Hegel hanya berlaku dalam hal penggunaan akal budi dominan yang mengabaikan kondisi faktual.

2. Biosentrisme

Berbeda dengan antroposentrisme yang menekankan kepada sikap tindak terhadap sesama manusia, biosentrisme menekankan bahwa alam juga memiliki nilai pada dirinya sendiri. Sehingga pendekatan ini menegaskan bahwa setiap kehidupan memiliki nilai. Di sini sudah ada pergeseran subjek moral, karena biosentrisme mendasarkan moralitas pada keluhuran kehidupan, baik pada manusia atau makhluk hidup lainnya. ${ }^{54}$ Dalam biosentris-

${ }^{52}$ J. Sudarminta, op.cit., hlm. 139.

${ }^{53}$ Ibid., hlm. 145

${ }^{54}$ A. Sonny Keraf, Etika Lingkungan, op.cit., hlm. 66. 
me, semua komunitas biotik harus diperlakukan secara moral. Namun harus dipahami bahwa pelaku moral-nya tetaplah manusia. Intinya manusia memiliki kewajiban moral terhadap alam karena kehidupan ini bersumber dan berdasarkan pada perimbangan nilai kehidupan manusia dan spesies lainnya (teori ini berpusat pada kehidupan). ${ }^{55}$ Sehingga jelaslah perbedaan antara biosentrisme dengan ekosentrisme yang memberikan ruang sampai kepada komunitas abiotik.

Terdapat beberapa alasan mengapa biosentrisme penting. Perta$m a$, keyakinan bahwa manusia adalah anggota komunitas kehidupan di bumi yang sama dengan makhluk hidup lainnya. Ke$d u a$, ada ketergantungan manusia terhadap alam yang ditentukan oleh relasi satu dengan yang lainnya. Ketiga, setiap makhluk hidup adalah pusat kehidupan yang memiliki tujuan hidupnya masing-masing. Keempat, bahwa manusia tidak lebih unggul dari makhluk lainnya. ${ }^{56}$

Biosentrisme sebagaimana arti sesungguhnya memang tidak dikenal dalam regulasi di Indonesia. Selain memang etika tidak harus dimuat dalam peraturan, garis besar regulasi lingkungan hidup Indonesia masih menekankan pada pendekatan antroposentrisme. Namun jika menilik kepada pembahasan penyusunan Undang-Undang Nomor 32 Tahun 2009 tentang Perlindungan dan Pengelolaan Lingkungan Hidup (UU 32/2009), maka biosentrisme menjadi ide dalam penyusunan konsep ekoregion. ${ }^{57}$ Ide ini memang tidak diterjemahkan secara sempurna ke dalam norma UU 32/2009, tetapi menjadi poin penting untuk menegaskan telah ada pemikiran (walaupun masih bercampur dengan ekosentrisme), untuk menaikkan pendekatan etika lingkungan.

Antroponsetrisme dan biosentrisme adalah dua pendekatan yang akan terus "bertarung" dan memang harus dipertarungkan melalui pemikiran akademik dalam mencapai idea mengenai konsepsi relasi ideal manusia dengan alam. Dalam perkembangannya, biosentrisme terlihat lebih memiliki relasi erat dengan lingkungan dibandingkan dengan antroposentrisme. Hal ini wajar karena efek samping dari pendekatan antroposentrisme adalah subjektivitas. Namun, subjektivitas bisa tidak menjadi dominan

${ }^{55}$ Ibid., hlm. 67.

${ }^{56}$ Paul Taylor, Respect for Nature: A Theory of Environmental Ethics (Princeton: Princeton University Press, 1986), hlm. 13, sebagaimana dikutip A. Sonny Keraf, Etika Lingkungan, hlm. 69.

${ }^{57}$ Dewan Perwakilan Rakyat Republik Indonesia, "Risalah RUU tentang Pengelolaan Lingkungan Hidup: RDPU dengan beberapa pakar, 16 Juli 2009", (Jakarta: Dewan Perwakilan Rakyat Republik Indonesia, 2009), hlm. 15. 
jika rumusan pokok etika deontologis Kant digunakan dengan tepat.

\section{V. "Tegangan" yang Muncul Akibat Relativisme Hukum}

Fenomena relativisme hukum hadir ketika penguasa memaksakan untuk membentuk dan menjalankan hukum sesuai dengan persepsi yang diyakininya. Pernyataan ini tidak menegasikan bahwa benar pemerintah memiliki kewenangan dalam membentuk dan menjalankan hukum. Mirip seperti relativisme moral, relativisme hukum hadir karena ukuran dari lahirnya kebijakan hukum adalah ukuran manusia, yaitu si pembuat kebijakan itu sendiri dan definisi keadilan ditentukan sepihak oleh penguasa. Tidak mengherankan bilamana pemerintah akan menyatakan bahwa hukum yang dibentuknya adalah adil. Sebagaimana yang telah disampaikan, bagian ini akan mengangkat kasus penerbitan izin lingkungan PT SI dan menguji apakah terjadi relativisme.

\section{Posisi kasus:}

Kasus ini bermula ketika izin lingkungan Pabrik PT SI di wilayah pegunungan Kendeng bagian Rembang digugat warga karena tidak partisipatif dan diterbitkan tidak dengan Amdal yang memadai. Pada akhirnya, MA mengabulkan permohonan Peninjauan Kem- bali Penggugat melalui Putusan No. 99/ PK/TUN/2016 yang menyatakan batal dan memerintahkan pemerintah untuk mencabut Surat Keputusan (SK) Gubernur Jawa Tengah Nomor 660.1/17 Tahun 2012, tanggal 7 Juni 2012, tentang Izin Lingkungan Kegiatan Penambangan oleh PT Semen Gresik (Persero) Tbk, di Kabupaten Rembang, Provinsi Jawa Tengah. Namun ketika kasus ini masih bergulir di MA, Pemerintah Provinsi Jawa Tengah secara tidak transparan telah memulai proses revisi Amdal dan permohonan izin lingkungan baru. Ketika pada tanggal 5 Oktober 2016 MA menyatakan batal dan memerintahkan pencabutan izin lingkungan lama, tanggal 9 November 2016 Gubernur mengeluarkan izin lingkungan hidup baru (SK Gubernur Jawa Tengah Nomor 660.1/30 Tahun 2016) dan mencabut izin lingkungan lama. Izin lingkungan baru ini diterbitkan tidak atas dasar putusan MA tetapi karena adanya perubahan kepemilikan ${ }^{58}$ dan perubahan luasan lahan.

Adapun pertimbangan Putusan No. 99/PK/TUN/2016 menyatakan Amdal cacat prosedur karena:

a. Peran serta masyarakat secara formal telah terpenuhi tetapi dengan adanya pernyataan sikap penolakan warga rembang belum mencerminkan keterlibatan atau keterwakilan setiap komponen masyarakat yang berpotensi

\footnotetext{
${ }^{58}$ Pergantian nama dari PT. Semen Gresik ke PT. Semen Indonesia.
} 
terkena dampak langsung atau tidak langsung;

b. Sosialisasi yang dilakukan belum dilaksanakan menurut yang seharusnya, pesan-pesan yang diharapkan belum sampai kepada sebagian masyarakat, sehingga persepsi positif yang harus diciptakan belum terwujud; dan

c. Amdal tidak memperhatikan Asas-Asas Umum Pemerintahan yang Baik (AUPB) kehati-hatian dan kecermatan dengan tidak memperlihatkan pembatasan dan tata cara penambangan di atas kawasan Cekungan Air Tanah (CAT), sehingga tidak dapat diperhitungan jaminan keberlangsungan sistem akuifier pada kawasan CAT. Bagian dokumen Amdal tidak memperlihatkan solusi yang konkret dan tidak tergambar cara alternatif penanggulannya terhadap masalah kebutuhan warga (air bersih dan pertanian).

Sedangkan secara substantif Putusan No. 99/PK/TUN/2016 menyatakan bahwa:

“...kegiatan penambangan dan pengeboran di atas CAT pada prinsipnya tidak dibenarkan. Namun demikian, untuk kepentingan bangsa dan negara yang sangat strategis dapat dikecualikan dengan pembatasan yang sangat ketat dan cara-cara tertentu serta terukur agar tidak mengganggu sistem akuifer. Penentuan izin lingkungan selayak- nya dilengkapi dengan persetujuan pejabat yang menetapkan status kawasan. Persetujuan berfungsi sebagai kebijakan dan politik lingkungan dan pembangunan, serta urgensi kepentingan bangsa dan negara."

Hal yang juga patut menjadi perhatian, para penggugat dan masyarakat baru mengetahui adanya SK Gubernur Jawa Tengah Nomor 660.1/30 Tahun 2016 pada tanggal 9 Desember 2016. Di kemudian hari, Gubernur Jawa Tengah kembali menerbitkan SK Gubernur Jawa Tengah Nomor 660.1/4 Tahun 2017 yang mencabut SK Gubernur Jawa Tengah Nomor 660.1/30 Tahun 2016. Adapun dasar pencabutan bukan karena putusan MA, melainkan memerintahkan PT SI untuk menyempurnakan berkas dokumen addendum Andal dan RKL-RPL untuk dinilai oleh Komisi Penilai Amdal Provinsi Jawa Tengah.

Dari posisi kasus tersebut, ada 3 fakta yang penting untuk dibahas. Pertama, secara administrasi penerbitan SK Gubernur Jawa Tengah Nomor 660.1/30 Tahun 2016 dan SK Gubernur Jawa Tengah Nomor 660.1/4 Tahun 2017 tidak berdasarkan Putusan No. 99/PK/TUN 2016. Kedua, SK Gubernur Jawa Tengah Nomor 660.1/30 Tahun 2016 diterbitkan setelah terbitnya Putusan No. 99/PK/ TUN/2016. Namun penggugat secara khusus dan masyarakat tidak pernah mengetahui proses penerbitan sampai 
terbitnya izin lingkungan tanggal 9 November 2016 tersebut. ${ }^{59}$ Ketiga, pertimbangan substantif Putusan No. 99/PK/ TUN/2016 mengenai boleh tidaknya penambangan di kawasan Karst Pegunungan Kendeng tidak pernah dipertimbangkan (diabaikan) dalam penerbitan SK Gubernur Jawa Tengah Nomor 660.1/30 Tahun 2016 dan terutama SK Gubernur Jawa Tengah Nomor 660.1/4 Tahun 2017.

Berdasarkan sedikitnya 3 fakta tersebut, fakta pertama jelas menunjukkan adanya penegasian terhadap institusi pengadilan. Seharusnya dalam proses penerbitan SK Gubernur Jawa Tengah Nomor 660.1/30 Tahun 2016, Gubernur Jawa Tengah mengetahui adanya Putusan No. 99/PK/TUN/2016. Fakta kedua, menunjukan bahwa proses penerbitan SK Gubernur Jawa Tengah Nomor 660.1/30 Tahun 2016 melanggar AUPB. Karena bagaimana mungkin penggugat dan masyarakat sama sekali tidak diberitahukan adanya proses penerbitan izin lingkungan baru, di saat Putusan No. 99/PK/TUN/2016 sudah "ramai" menjadi bahasan publik.

Adapun fakta ketiga menunjukkan nihilnya perspektif etika lingkungan dari Gubernur Jawa Tengah dalam menerbitkan SK Gubernur Jawa Tengah Nomor 660.1/30 Tahun 2016 dan SK Gu- bernur Jawa Tengah Nomor 660.1/4 Tahun 2017. Dari pertimbangan MA, jelas bahwa pengeboran dan penambangan di atas CAT tidak diperkenankan. Pengecualiannya hanya untuk kepentingan strategis bangsa, tetapi dengan pembatasan yang sangat ketat yang tidak mengganggu sistem akuifer (lihat cetak tebal pertimbangan).

Dalam menguji fakta ketiga, maka perlu memperhatikan Peraturan Daerah Provinsi Jawa Tengah Nomor 6 Tahun 2010 tentang Rencana Tata Ruang Wilayah Provinsi Jawa Tengah Tahun 2009-2029. Dalam Perda RTRW tersebut, kawasan CAT Watuputih ditetapkan sebagai kawasan lindung, yaitu kawasan imbuhan air tanah. Selanjutnya, berdasarkan Pasal 40 ayat (1) dan ayat (2) Peraturan Pemerintah Nomor 43 Tahun 2008 tentang Air Tanah, melarang adanya kegiatan pengeboran, penggalian atau kegiatan lain dalam radius 200 meter dari lokasi pemunculan mata air. Sehingga dari uraian ini, pengecualian yang diberikan oleh Putusan No. 99/ PK/TUN/2016, sangat sulit atau tidak mungkin dapat terlaksana. Artinya penambangan, pengeboran, dan kegiatan lainnya di atas CAT Watuputih sama sekali tidak diperkenankan.

Terhadap uraian ketiga fakta di atas dan pengujian relativisme yang dilaku-

${ }^{59}$ LBH Jakarta, "Pendapat Hukum Tentang Putusan MA dan Izin Pembangunan Pabrik Semen di Rembang," https://www.bantuanhukum.or.id/web/pendapat-hukum-tentang-putusan-ma-danizin-pembangunan-pabrik-semen-di-rembang/, diakses tanggal 20 Maret 2019. 
kan oleh Gubernur Jawa Tengah, maka diperlukan alat bantu sebagaimana yang telah disampaikan pada bagian kedua yang didasarkan dari pemikiran Protagoras dan Thrasymakhos serta subjek- tivitas yang mengabaikan sikap etis terhadap alam yang telah diuraikan pada bagian keempat. Alat bantu tersebut berupa pertanyaan yang diuraikan dalam tabel berikut:

\begin{tabular}{|l|l|}
\hline \multicolumn{1}{|c|}{ Pertanyaan } & \multicolumn{1}{|c|}{ Izin Lingkungan PT. Semen Indonesia } \\
\hline $\begin{array}{l}\text { Apakah persepsi pemerintah } \\
\text { menjadi faktor terbesar yang } \\
\text { mempengaruhi munculnya } \\
\text { hukum tersebut? }\end{array}$ & $\begin{array}{l}\text { Ya. Persepsi subjek tersebut terlihat dari sikap } \\
\text { Gubernur Jawa Tengah yang ingin tetap } \\
\text { melanjutkan proyek PT. Semen Indonesia. } \\
\text { Walaupun dalam pernyataan di media massa } \\
\text { Gubernur Jawa Tengah menyatakan telah } \\
\text { memenuhi Putusan No. 99/PK/TUN/2016, } \\
\text { tetapi pada faktanya hanya melakukan } \\
\text { penyempurnaan Amdal agar izin lingkungan } \\
\text { dapat kembali diterbitkan. }\end{array}$ \\
\hline $\begin{array}{l}\text { Apakah terjadi pengeyampingan } \\
\text { data dalam membentuk hukum? }\end{array}$ & $\begin{array}{l}\text { Ya. Putusan No. 99/PK/TUN/2016, terutama } \\
\text { pertimbangan substantif dikesampingkan } \\
\text { dalam penerbitan izin lingkungan baru. }\end{array}$ \\
\hline $\begin{array}{l}\text { Apakah hukum digunakan } \\
\text { sebagai alat legitimasi? }\end{array}$ & $\begin{array}{l}\text { Ya. Prosedural penerbitan izin dianggap sudah } \\
\text { memenuhi Putusan No. 99/PK/TUN/2016. } \\
\text { Akibatnya proyek PT SI dapat kembali berjalan } \\
\text { dengan memenuhi Surat Keputusan Gubernur } \\
\text { Jawa Tengah Nomor 660.1/4 Tahun 2017. } \\
\text { Walaupun tidak menjawab pertimbangan } \\
\text { substantif Putusan No. 99/PK/TUN/2016. }\end{array}$ \\
\hline $\begin{array}{l}\text { Apakah proses pembentukan } \\
\text { produk hukum menegasikan } \\
\text { institusi-institusi } \\
\text { hukum? penegakan }\end{array}$ & $\begin{array}{l}\text { Ya. SKGubernur Jawa Tengah Nomor 660.1/30 } \\
\text { Tahun 2016 dan terutama Surat Keputusan } \\
\text { Gubernur Jawa Tengah Nomor 660.1/4 Tahun } \\
\text { 2017 jelas-jelas menegasikan Putusan No. 99/ } \\
\text { PK/TUN/2016. Pengabaian terhadap institusi } \\
\text { MA menjelaskan bahwa nilai keadilan dalam } \\
\text { kasus ini berasal dari persepsi subjektif dari } \\
\text { Gubernur Jawa Tengah. }\end{array}$ \\
\hline
\end{tabular}

Tabel 3. Pengecekan Relativisme Hukum 
Berdasarkan tabel di atas maka penerbitan SK Gubernur Jawa Tengah Nomor 660.1/30 Tahun 2016 dan terutama SK Gubernur Jawa Tengah Nomor 660.1/4 Tahun 2017 tepat dikatakan sebagai relativisme hukum. Tindakan Gubernur Jawa Tengah ini jelas-jelas menekankan kepada penyalahgunaan pendekatan antroposentrisme, ${ }^{60}$ karena jelas pertimbangan dari kedua produk hukum ini adalah kepentingan pembangunan dan ekonomi, sehingga mengenyampingkan relevansi manusia dengan alam. Hal ini Karena seolah-olah pembangunan proyek PT SI menjadi nilai utama yang dapat menegasikan keberadaan masyarakat dan lingkungan hidup.

Kembali ke dalam konteks teori etika lingkungan, walaupun antroposentrisme menekankan manusia sebagai pusat, tetapi pendekatan relasi manusia dengan alam tidak dapat diabaikan. Sehingga tidak dapat dimaknai bahwa manusia adalah segala-galanya dan mempertimbangkan kepentingan alam hanya berdasarkan persepsinya. Dalam relasi dengan alam, etika deontologis Kant menjadi penting untuk diterapkan.

Dua permasalahan etis muncul dalam pembentukan produk hukum ini. Pertama masalah etis muncul karena adanya relativisme hukum di sana. Mo- ralitas Gubernur Jawa Tengah dipertanyakan ketika prosedural penerbian izin dianggap sudah memenuhi Putusan No. 99/PK/TUN/2016. Mengacu kepada UU 32/2009, kewenangan bagi pemerintah pusat dan pemerintah daerah dalam menerbitkan izin lingkungan memang diperkenankan. Namun, sebagai manusia yang hakikat eksistensinya tidak terpisahkan dengan alam, maka ia memiliki kewajiban memelihara kelestarian dan mengendalikan pencemaran dan/ atau kerusakan lingkungan hidup. Ketentuan ini perlu dipertegas bahwa kewajiban individu tidak terbatas kepada kewenangan jabatan yang dimilikinya. Artinya dalam hal individu pengemban esensi sebagai makhluk hidup, maka sikap hormatnya kepada alam adalah hal mutlak dalam menjaga relasi diantaranya. Pengertian ini lebih dari sekadar menjalankan kewajiban, melainkan kemurnian akal budi dan sikap tindak.

Kedua, masalah etis juga muncul tidak lepas dari penyalahgunaan pendekatan antroposentrisme. Walaupun kepentingan manusia yang menjadi pusatnya, tetapi tidak serta merta dibenarkan untuk melakukan eksploitasi alam dengan tidak bijak. Hal ini menegaskan tidak juga bahwa biosentrisme mutlak menjadi jawabannya. ${ }^{61}$ Kuncinya keti-

${ }^{60}$ Sebagaimana telah dijelaskan, etika secara umum memang hanya mengatur manusia. Lahirnya etika lingkungan juga tidak serta merta menghilangkan atau menolak secara ketat antroposentrisme. Penulis berpendapat keduanya dapat dihubungkan oleh etika deontologis Kant.

${ }^{61} \mathrm{Hal}$ ini perlu diuji dalam penelitian lebih lanjut. 
ka pendekatan antroponsetrisme secara garis besar mewarnai jalannya suatu pemerintahan, maka perlu dijalankan dengan tetap menghormati alam. Intinya, dengan banyak kelemahan pendekatan antroposentrisme, secara imperatif kategoris sikap tindak manusia terhadap alam harus tetap mencerminkan hormat kepada alam.

\section{Penutup}

Menyatakan bahwa penerbitan SK Gubernur Jawa Tengah Nomor 660.1/30 Tahun 2016 dan terutama SK Gubernur Jawa Tengah Nomor 660.1/4 Tahun 2017 sebagai relativisme hukum sudah menunjukkan adanya masalah etis yang dilakukan oleh Gubernur Jawa Tengah. Namun pernyataan mengenai problematika moral yang dilakukan Gubernur Jawa Tengah perlu dicatat sebagai pelanggaran untuk dibaca dari masa ke masa sebagai bahan pembelajaran. Moral adalah esensi dari manusia berakal budi, kritik terhadap moral berarti sebagai respon atas esensinya sebagai makhluk hidup. Hal penting lainnya adalah, pendekatan antroposentrisme tidak dapat dijadikan dasar pembenar dari lahirnya produk hukum di atas. Antroposentrisme bukan pendekatan yang buruk, tetapi penyalahgunaannya yang menghasilkan problematika etis. Perlu dipahami secara mendasar, bahwa alam dan segala isinya bukan bersifat tidak tak terbatas. Karenanya memahami alam adalah inti dari sikap tindak manusia terlepas dari pendekatan apapun yang digunakan. Dalam kasus ini, Gubernur Jawa Tengah menunjukkan rendahnya sikap hormat terhadap alam. 


\section{DAFTAR PUSTAKA}

\section{Peraturan Perundang-Undangan}

Indonesia. Undang-Undang Perlindungan dan Pengelolaan Lingkungan Hidup. UU No. 32 Tahun 2009. LN No. 140 Tahun 2009. TLN No. 5059.

Menteri Lingkungan Hidup dan Kehutanan. Peraturan Menteri Lingkungan Hidup dan Kehutanan tentang Perubahan Kedua atas Peraturan Menteri Lingkungan Hidup dan Kehutanan No P.20/MENLHK/ SETJEN/KUM.1/6/2018 tentang Jenis Tumbuhan dan Satwa yang Dilindungi. No. 106 Tahun 2018.

Menteri Lingkungan Hidup dan Kehutanan. Peraturan Menteri Lingkungan Hidup dan Kehutanan tentang Jenis Tumbuhan dan Satwa yang Dilindungi. No. 20 Tahun 2018.

\section{Buku}

Bertens, K. Etika. Yogyakarta: PT Kanisius, 2013.

Descartes, René. Meditation on First Philosophy. New York: Oxford University Press Inc, 2008.

Dimiyati, Khudzaifah et.al. Hukum dan Moral: Basis Epistemologi Paradigma Rasional H.L.A. Hart.Yogyakarta: Genta Publishing, 2017.

Hamersma, Harry. Pintu Masuk Ke Dunia Filsafat. Yogyakarta: Yayasan Kanisius, 1981.
Keraf, A. Sonny. Etika Lingkungan Hidup. Jakarta: PT Kompas Media Nusantara, 2010.

Keraf, A. Sonny. Filsafat Lingkungan Hidup: Alam Sebagai Sebuah Sistem Kehidupan. Yogyakarta: PT Kanisius, 2014.

Leahy, Louis, Siapakah Manusia? Sintesis Filosofis tentang Manusia. Yogyakarta: Penerbit Kanisius, 2001.

Mill, John Stuart. On Liberty. Jakarta: Yayasan Obor Indonesia, 2005.

Setyo Wibowo, A. Paideia: Filsafat Pendidikan-Politik Platon. Yogyakarta: Penerbit Kanisius, 2017.

Shomali, Mohammad A. Relativisme Etika: Analisis Prinsip-Prinsip Moralitas. Jakarta: Shadra Press. 2011.

Sudarminta, J. Etika Umum: Kajian tentang Beberapa Masalah Pokok dan Teori Etika Normatif. Yogyakarta: PT Kanisius. 2013.

Suseno, Franz Magnis. Etika Dasar: Masalah-Masalah Pokok Filsafat Moral. Yogyakarta: PT Kanisius, 1987.

Plato. Theaetetus. terjemahan oleh John McDowell. Oxford: Clarendon Press, 1973.

\section{Artikel Jurnal/Media Massa}

Bloomer, W. Martin (ed). A Companion to Ancient Education: Blackwell companions to the ancient world. John Wiley \& Sons, 2015. 
Carson, Rachel. Silent Spring. New York: Fortieth Anniversary Edition, A Mariner Book, Houghton Mifflin Company, 2002.

Damar Sinuko, "Ganjar Patuhi Putusan MA Cabut Izin Semen Rembang" Www.cnnindonesia.com/nasional/20170116200519-20-186754/ganjar-penuhi-putusan-ma-cabut-izinsemen-rembang, diakses pada 21 Maret 2019.

LBH Jakarta, “ Analisa Hukum Terhadap Surat Keputusan Gubernur Jawa Tengah Terkait Izin Pabrik Semen di Rembang" https://www.bantuanhukum.or.id/web/analisa-hukumterhadap-surat-keputusan-gubernur-jawa-tengah-terkait-izin-pabriksemen-di-rembang/, diakses pada 21 Maret 2019.

LBH Jakarta, "Pendapat Hukum Tentang Putusan MA dan Izin Pembangunan Pabrik Semen di Rembang," https:/ / www.bantuanhukum.or.id/web/ pendapat-hukum-tentang-putusanma-dan-izin-pembangunan-pabriksemen-di-rembang/, diakses pada 20 Maret 2019.

Setyo Wibowo, A. "Pengantar Sejarah Filsafat Yunani: Sofisme". (Makalah untuk Kelas Filsafat Yunani Kuno: Kaum Phusikoi di Serambi Salihara 12 Maret 2016).

Shields, Christopher (ed). The Blackwell Guide to Ancient Philosophy. Blackwell Publishing Ltd, 2003.
Singer, Peter. "Animal Liberation at 30*" http:/ / www.animal-rights-library. com/texts-m/singer04.pdf, diakses pada 20 Maret 2019.

Westermarck, Edward. Ethical Relativity. London: Kegan Paul, Trench, Trubner \& Co Ltd. 1932.

\section{Lain-lain}

Dewan Perwakilan Rakyat Republik Indonesia, "Risalah RUU tentang Pengelolaan Lingkungan Hidup". Jakarta: Dewan Perwakilan Rakyat Republik Indonesia, 2009. 